\title{
ANALISIS KEBUTUHAN PENDIDIKAN DAN PELATIHAN PEGAWAI NEGERI SIPIL PADA BADAN KEPEGAWAIAN DAN PENGEMBANGAN SUMBER DAYA MANUSIA KOTA TIDORE KEPULAUAN
}

\section{ANALYSIS OF TRAINING NEED ANALYSIS AT THE BOARD OF EMPLOYEE AND HUMAN RESOURCE DEVELOPMENT OF TIDORE KEPULAUAN MUNICIPALITY}

\author{
Abdurrahman ${ }^{1}$ dan Halim ${ }^{2}$ \\ ${ }^{1}$ Badan Kepegawaian dan Pengembangan Sumber Daya Manusia Kota Tidore Kepulauan. \\ e-mail: mayankiki.man@gmail.com \\ ${ }^{2}$ Sekolah Tinggi Ilmu Administrasi-Lembaga Administrasi Negara, Makassar \\ e-mail: halim.recht@gmail.com
}

\begin{abstract}
Abstrak
Pendidikan dan Pelatihan diperlukan untuk mengatasi kesenjangan antara kualitas pelaksanaan tugas dengan standar kualitas minimal yang dibutuhkan, serta untuk meningkatkan kualitas kerja. Penelitian ini bertujuan untuk mengetahui dan menganalisis pelaksanaan analisis kebutuhan pendidikan dan pelatihan bagi Pegawai Negeri Sipil pada Badan Kepegawaian dan Pengembangan Sumber Daya Manusia (BKPSDM) Kota Tidore Kepulauan. Penelitian ini menggunakan metode kualitatif. Unit Analisis terdiri atas 8 Informan serta dokumen-dokumen yang diperoleh dari BKPSDM Kota Tidore Kepulauan yakni Dokumen Rencana Strategik, Dokumen Laporan Akuntabilitas Kinerja, dan Dokumen Analisis Jabatan. Data dianalisis secara kualitatif. Hasil penelitian memperlihatkan bahwa Badan Kepegawaian dan Pengembangan Sumber Daya Manusia Kota Tidore Kepulauan tidak melakukan analisis kebutuhan pendidikan dan pelatihan dengan tepat dan sistematis. Identifikasi kebutuhan pendidikan dan pelatihan di tingkat organisasi hanya ditentukan oleh pimpinan, identifikasi kebutuhan pendidikan dan pelatihan ditingkat pekerjaan hanya menyesuaikan dengan program-program pendidikan dan pelatihan yang ditawarkan oleh penyelenggara dan kebutuhan di tingkat individu hanya diputuskan oleh pimpinan berdasarkan intuisi dan keinginannya. Oleh karena itu, sebaiknya BKPSDM Kota Tidore Kepulauan dalam menentukan bagian atau bidang mana dalam organisasi yang membutuhkan diklat dilaksanakan melalui proses analisis organisasi dengan melakukan wawancara keluar, survai Calon Peserta dan data kepuasan peserta maupun dengan melihat indeks efisiensi.
\end{abstract}

Kata kunci: Analisis Kebutuhan Pendidikan dan Pelatihan, Pengembangan Sumber Daya Manusia, Pemerintah Kota Tidore Kepulauan.

\footnotetext{
Abstract

Education and Training are needed to address the gap between the quality of task performance and the minimum quality standards required, as well as to improve the quality of work. The objective of this study is to understand and analyze the
} 
implementation of training needs analysis for Civil Servants that was undertaken by The Board of Employee and Human Resource Development of Tidore Kepulauan Municipality. This study uses a qualitative method. Analysis Unit is 8 informants and documents obtained from BKPSDM Tidore Kepulauan Municipality namely Document of Strategic Plan, Document of Performance Accountability Report, Job Analysis Document. Data were analyzed qualitatively. The results of the study show that The Board of Employee and Human Resource Development of Tidore Kepulauan Municipality did not conduct a proper and systematic training needs analysis. The training needs identification at the organizational level is determined solely by the leader, the training needs identification at the job level merely adjusting to the education and training programs offered by the organizers and the individual level needs only decided by the leadership based on intuition and desire. Therefore, it is better to BKPSDM Tidore Kepulauan Municipality in determining which part or field in the organization that need the training done through organizational analysis process by conducting out interview, participant survey and participant satisfaction data as well as by looking at the efficiency index.

Keywords: Training Needs Analysis, Human Resource Development, Tidore Kepulauan Municipality.

\section{PENDAHULUAN}

Pendidikan dan Pelatihan (Diklat) bertujuan untuk memperbaiki Prestasi Kerja Pegawai dalam mencapai hasil yang telah ditetapkan. Diklat dibutuhkan untuk mengatasi kesenjangan antara kualitas pelaksanaan tugas dengan standar kualitas minimal yang diperlukan serta untuk meningkatkan kualitas kerja. Diklat yang diikuti Pegawai seyogianya didasarkan pada hal yang dinilai masih kurang, hal yang ingin ditingkatkan, serta hal yang dianggap perlu dipersiapkan Pegawai sebagai persiapan untuk menghadapi tantangan masa depan. Untuk itu kegiatan diklat yang dilaksanakan harus direncanakan dengan tepat melalui proses analisis kebutuhan diklat secara akurat memberikan informasi kebutuhan instansi agar dapat menciptakan, memperbaiki, dan/atau meningkatkan kompetensi Pegawai guna menunjang kinerja dalam mencapai tujuan organisasi. Analisis kebutuhan diklat dapat dilakukan melalui tiga tingkatan atau tahapan analisis yaitu analisis organisasi, analisis pekerjaan/tugas, dan analisis individu (Mondy, 2008). Analisis organisasi bertujuan untuk mengetahui pada bagian/bidang mana diklat dibutuhkan dalam suatu organisasi, analisis pekerjaan/tugas bertujuan untuk mengetahui program diklat yang layak dan dibutuhkan dalam menunaikan tugas/pekerjaan yang ada, dan analisis individu bertujuan untuk mengetahui siapa saja Pegawai yang harus dan layak diikutkan dalam suatu program diklat.

Badan Kepegawaian dan Pengembangan Sumber Daya Manusia (BKPSDM) Kota Tidore Kepulauan selama ini selalu melaksanakan program pengembangan Pegawai Negeri Sipil (PNS) melalui kegiatan diklat penjenjangan maupun diklat fungsional, yang dilaksanakan di dalam daerah maupun di luar daerah, namun sekian banyak kegiatan diklat yang telah dilaksanakan untuk PNS selama ini tidak berbanding lurus dengan peningkatan kompetensi sebagaimana yang diharapkan dari Pegawai yang mengikuti program tersebut, hal ini tergambar pada perilaku kurang disiplin dan kinerja yang kurang baik. Sebagaimana terungkap melalui informasi yang Penulis temukan pada surat kabar harian Malut Post edisi Selasa, 12 Juli 2016, yang memberitakan bahwa terdapat 10\% PNS yang tak masuk kantor pascalibur hari raya, yang mana di dalamnya juga terdapat beberapa 
oknum Pegawai BKPSDM Kota Tidore Kepulauan. Selain itu, terdapat pula berita tentang ketidaktahuan BKPSDM Kota Tidore Kepulauan tentang adanya Tenaga Honorer di beberapa SKPD (harian Malut Post edisi Kamis, 21 Juli 2016). Hal ini menunjukan bahwa manajemen kepegawaian di lingkungan Pemerintah Kota Tidore Kepulauan belum terintegrasi dengan baik.

Uraian permasalahan di atas menggambarkan adanya kesenjangan atau gap antara kondisi yang seharusnya dengan realitas yang ada, kegiatan diklat yang telah dilaksanakan selama ini belum bisa secara efektif dan efisien menutupi kesenjangan yang terjadi antara kondisi kinerja yang diharapkan dengan kondisi kompetensi PNS yang ada saat ini di BKPSDM Kota Tidore Kepulauan sehingga berimplikasi pada prestasi kerja organisasi. Oleh karena itu, analisis kebutuhan diklat harus menjadi fokus perhatian dalam perencanaan pengembangan sumber daya manusia. Untuk itu tujuan penelitian adalah untuk mengetahui dan menganalisis pelaksanaan analisis kebutuhan Diklat PNS di BKPSDM Kota Tidore Kepulauan melalui tahapan analisis organisasi, tahapan analisis pekerjaan, dan tahapan analisis individu.

\section{METODE PENELITIAN}

\section{Tipe Penelitian}

Penelitian ini bersifat deskriptif dengan pendekatan kualitatif bertujuan untuk mengkaji dan mengamati kenyataan secara mendalam di lapangan terhadap variabel yang dikaji dengan menggunakan instrumen penelitian yang relevan.

\section{Unit Analisis}

Data yang digunakan dalam penelitian ini adalah data primer dan data sekunder. Data primer dalam analisis kebutuhan Diklat ini adalah informasi yang didapatkan melalui wawancara yang akan digali dari informan sebanyak 8 orang di BKPSDM Kota Tidore Kepulauan dan Sekretariat Daerah Kota Tidore Kepulauan, sementara data sekundernya adalah dokumen-dokumen yang diperoleh dari BKPSDM Kota Tidore Kepulauan, di antaranya adalah Dokumen Rencana Strajeik (RENSTRA), Dokumen Laporan Akuntabilitas Kinerja (LAKIP), Dokumen Analisis Jabatan (ANJAB), dan Dokumendokumen lainnya yang dianggap penting dan relevan dengan konteks penelitian ini.

\section{Teknik dan Instrumen Pengumpulan Data}

Teknik pengumpulan data dalam penelitian ini yaitu wawancara menggunakan pedoman wawancara semi terstruktur dengan garis-garis besar yang akan ditanyakan sesuai dengan topik penelitian dan dalam mengembangkan pertanyaan yang diajukan sangat bergantung pada pemahaman konsep dan spontanitas peneliti. Di samping itu, dilakukan observasi atau pengamatan secara langsung oleh peneliti tentang halhal yang relevan. Pengamatan dilakukan untuk memperoleh keterangan dan informasi untuk mengetahui relevansi antara jawaban informan dan kenyataan yang ada. Selain itu, dilakukan telaah dokumen dengan menggunakan data sekunder yang bersumber dari seluruh dokumen-dokumen yang menunjang penelitian ini dan pengambilan gambar (foto-foto) tentang hal-hal yang relevan.

\section{Teknik Pengolahan dan Analisis Data}

Teknik pengolahan dan analisis data dalam penelitian ini menggunakan analisis data interaktif (interactive model of analysis) yang meliputi pengumpulan data, reduksi data, penyajian data, dan penarikan kesimpulan berlandaskan teori. 


\section{HASIL PENELITIAN}

\section{Pelaksanaan Kebutuhan Diklat BKPSDM Kota Tidore Kepulauan Melalui Analisis Organisasi}

Berdasarkan hasil wawancara (19 Juni 2017) dengan Sekretaris Daerah dan Asisten III bidang Administrasi Kota Tidore Kepulauan mengenai penentuan kebutuhan diklat dikaitkan dengan visi, misi, dan rencana stratejik (analisis organisasi), diketahui bahwa visi, misi, rencana stratejik dan hasil perencanaan sumber daya manusia merupakan rujukan yang harus dipertimbangkan dalam melakukan analisis kebutuhan diklat. Kegiatan pengembangan sumber daya manusia sangat bergantung pada ketersediaan anggaran dimana anggaran untuk kegiatan belanja Pegawai terbatas sehingga kegiatan pengembangan Sumber Daya Manusia lebih diprioritaskan pada kegiatan diklat prajabatan maupun diklat kepemimpinan, untuk kegiatan diklat teknis fungsional lainnya yang disetujui hanya yang sifatnya penting dan mendesak. Untuk menentukan pada bagian mana diklat dibutuhkan diserahkan kepada BKPSDM untuk melakukan analisis kebutuhan diklat secara mandiri sesuai dengan kebutuhan organisasi.

Kemudian berdasarkan informasi dari Kepala BKPSDM Kota Tidore Kepulauan (Wawancara, 19 Juni 2017), menyatakan bahwa:

"Ya sebelumnya kami melakukan analisis kebutuhan. Visi, misi, rencana stratejik dan hasil perencanaan sumber daya manusia itu semua sudah pasti menjadi pertimbangan kami dalam menentukan kebutuhan diklat. Saya biasanya berdiskusi dengan Sekretaris, Kepala-kepala Bidang, kadang-kadang juga dengan kasubag/ kasubid juga dengan staf di saat rapat maupun bacarita biasa dengan mereka tentang kendala-kendala apa yang mereka hadapi dalam melaksanakan program kerja yang ada, kalau ada peraturan maupun kebijakan baru juga sering kami diskusikan bersama. Itu semua menjadi masukan buat saya untuk menentukan bagian atau bidang mana yang harus melaksanakan diklat pada tahun anggaran ini misalnya. Kalau Diklat Teknis diinternal BKPSDM biasanya dalam penyusunan RKA, bidang-bidang maupun bagian sekretariat dorang selalu mengajukan kegiatan diklat masing-masing tinggal kita lihat yang mana punya lebih penting dan mendesak itu yang diakomodir, itu pun tergantung anggaran mencukupi atau tidak. Kalau diklat struktural itu sudah jelas selain berdasarkan dan PP 101 Tahun 2000 tentang diklat PNS kami juga merujuk Perka LAN Nomor 18, 19, dan 20 Tahun 2015 tentang pedoman penyelenggaraan Diklat Pim”.

Penjelasan dari Kepala Badan BKPSDM Kota Tidore Kepulauan menunjukan bahwa dalam melakukan analisis kebutuhan diklat di lingkup internal BKPSDM merujuk pada visi, misi, rencana stratejik dan hasil perencanaan sumber daya manusia, adapun cara dalam melakukan analisis tersebut masih sangat bergantung pada penilaian Pimpinan dengan merujuk pada kebijakan diklat aparatur, walaupun informasi-informasi yang digunakan sebagai bahan analisis bersumber dari hasil diskusi atau komunikasi dengan setiap Pejabat Struktural serta Staf yang ada, namum dalam menentukan bagian mana yang harus dilaksanakan kegiatan diklat dan dimasukan dalam program kegiatan sangat bergantung pada intuisi atau keinginan.

Kondisi tersebut sejalan dengan keterangan yang diperoleh Peneliti dari Kepala Bidang Pengembangan Sumber Daya Aparatur (Wawancara, 19 Juni 2017), menyatakan bahwa:

"Kami di Bidang Pengembangan Sumber Daya Aparatur melakukan 
analisis kebutuhan kami, setiap tahun anggaran kami selalu sodorkan diklat yang kami butuhkan, tergantung nanti dalam rapat pembahasan anggaran disetujui atau tidak, itu tergantung pimpinan (red: Kepala BKPSDM) untuk dimasukan dalam program kegiatan. Dalam menganalisa kebutuhan diklat kami tentu memperhatikan visi, misi dan rencana stratejik juga hasil perencanaan sumber daya manusia yang ada. Saya bersama dengan staf-staf saya samasama merumuskan yang menjadi kebutuhan kami, tapi itu kembali kepada pimpinan diterima atau tidak".

Pernyataan Kepala Bidang Pengembangan Sumber Daya Aparatur tersebut menunjukkan bahwa dalam melakukan analisis kebutuhan diklat khususnya dalam menentukan bagian/ bidang mana di BKPSDM yang layak dilaksanakan kegiatan diklat sangat bergantung pada penilaian Pimpinan
Tidore Kepulauan masih rendah. Hal ini terlihat dari suasana apel pagi dan sore, Pegawai yang mengikuti apel pagi ternyata tidak mencukupi setengah dari jumlah Pegawai secara keseluruhan yaitu hanya tujuh belas orang dari tiga puluh lima PNS yang ada. Di samping itu, Pegawai semakin berkurang pada apel yang dilaksanakan di sore harinya hanya tersisa dua belas orang pegawai. Adapun sikap yang kurang baik yang dilakukan oleh Oknum Pegawai dalam pelaksanaan apel pagi terlihat masih ada Pegawai yang masih sibuk dengan telepon selulernya pada saat Kepala Badan sedang memberikan pengarahan.

Kemudian dari dokumen hasil perencanaan diklat teknis yang diperoleh dari Bidang Pengembangan Sumber Daya Aparatur maupun dari Sub Bagian Perencanaan dan keuangan BKPSDM Kota Tidore Kepulauan diketahui hal-hal pada tabel berikut ini:

Tabel 1

(Kepala BKPSDM) meskipun setiap bidang maupun bagian telah $\mathrm{m}$ e $\mathrm{r} \mathrm{u} \mathrm{m} \mathrm{u} \mathrm{s} \mathrm{k} \mathrm{a} \mathrm{n}$ kebutuhannya, namun selanjutnya tergantung pada intuisi atau pendapat Pimpinan yang lebih penting dan mendesak melaksanakan kegiatan diklat, itu pun sangat bergantung pada ketersediaan anggaran.

BKPSDM Kota Tidore Kepulauan memiliki tujuan meningkatkan kualitas manajemen kepegawaian berbasis teknologi sekaligus bertujuan meningkatkan kapasitas Aparatur berdasarkan kompetensi Keterlibatan Bagian/Bidang dalam Pelaksanaan Kegiatan Diklat Teknis Di BKPSDM Kota Tidore Kepulauan

\begin{tabular}{|l|l|l|l|}
\hline No & Nama Diklat & $\begin{array}{l}\text { Bagian/Bidang } \\
\text { Yang dilibatkan }\end{array}$ & $\begin{array}{l}\text { Jumlah } \\
\text { Peserta }\end{array}$ \\
\hline 1 & Diklat Pengadaan Barang dan Jasa & Sekretariat & 2 Orang \\
\hline 2 & Diklat Perhitungan Angka Kredit & Mutasi & 5 Orang \\
\hline 3 & Diklat Penyusunan Formasi PNS & $\begin{array}{l}\text { Pengadaan Pembianaan } \\
\text { dan Informasi }\end{array}$ & 2 Orang \\
\hline 4 & $\begin{array}{l}\text { Diklat Manajemen Of Training } \\
\text { (MOT) }\end{array}$ & $\begin{array}{l}\text { Pengembangan Sumber } \\
\text { Daya Aparatur }\end{array}$ & 4 Orang \\
\hline 5 & Diklat Akrual & $\begin{array}{l}\text { 1. Sekretariat, } \\
\text { 2. Pengadaan Pembinaan } \\
\text { dan Informasi, }\end{array}$ & 3 Orang \\
\hline 6 & $\begin{array}{l}\text { Diklat Penyusunan RKA, Penyusunan } \\
\text { SPJ Bendahara Pengeluaran dan Pajak }\end{array}$ & Sekretariat & 4 Orang \\
\hline 7 & $\begin{array}{l}\text { Diklat Penyusunan Renstra dan } \\
\text { Pengelolaan Barang Milik Daerah } \\
\text { Menggunakan Aplikasi }\end{array}$ & Sekretariat & 5 Orang \\
\hline
\end{tabular}

Sumber: Olahan Data Sekunder, 2017.

serta meningkatkan disiplin PNS, namun berdasarkan hasil observasi ditemukan kenyataan yang menunjukan tingkat kedisiplinan pegawai di BKPSDM Kota
Tabel 1 menunjukkan bahwa BKPSDM Kota Tidore Kepulauan dalam menentukan bagian/bidang yang mengikuti diklat masih didominasi oleh peserta diklat dari Bagian Sekretariat. 
2. Pelaksanaan Kebutuhan Diklat BKPSDM Kota Tidore Kepulauan Melalui Analisis Pekerjaan

Berdasarkan penjelasan singkat mengenai deskripsi pekerjaan dan spesifikasi pekerjaan yang yang tersedia pada BKPSDM Kota Tidore Kepulauan jika disandingkan dengan data tentang kegiatan diklat teknis yang pernah dilaksanakan BKPSDM Kota Tidore Kepulauan, maka dapat dikatakan bahwa penentuan jenis kegiatan diklat yang telah dilaksanakan selama ini masih relevan dengan kebutuhan pekerjaan atau tugas yang ada di Badan Kepegawaian dan Pengembangan Sumber Daya Manusia Kota Tidore Kepulauan, kondisi tersebut dapat dilihat dalam tabel berikut:

Tabel 2

Relevansi Diklat yang Dilaksanakan dengan Pekerjaan / Tugas

Pada BKPSDM Kota Tidore Kepulauan

\begin{tabular}{|c|c|c|c|}
\hline No & Nama Diklat & Pekerjaan / TugasYang Relevan & $\begin{array}{c}\text { Penyelenggara } \\
\text { \&Tempat Pelaksanaan }\end{array}$ \\
\hline 1 & $\begin{array}{l}\text { Diklat Pengadaan } \\
\text { Barang dan Jasa }\end{array}$ & \begin{tabular}{|l|} 
- Melakukan urusan perlengkapan badan \\
- Melakukan urusan kerumahtanggaan badan
\end{tabular} & $\begin{array}{c}\text { Badan Diklat Prov. Malut } \\
\text { Ternate }\end{array}$ \\
\hline 2 & \begin{tabular}{|l|} 
Diklat Perhitungan \\
Angka Kredit
\end{tabular} & \begin{tabular}{|l|} 
Melaksanakan urusan kenaikan pangkat dan \\
kenaikan gaji berkala
\end{tabular} & $\begin{array}{c}\text { BKN } \\
\text { Manado }\end{array}$ \\
\hline 3 & \begin{tabular}{|l|} 
Diklat Penyusunan \\
Formasi PNS
\end{tabular} & $\begin{array}{l}\text { - Melakukan analisis kebutuhan calon ASN } \\
\text { - Melaksanakan pengadaan calon ASN }\end{array}$ & $\begin{array}{c}\text { BKN } \\
\text { Manado }\end{array}$ \\
\hline 4 & $\begin{array}{l}\text { Diklat Managemen } \\
\text { Of Training (MOT) }\end{array}$ & $\begin{array}{l}\text { - Melaksanakan fasilitasi pendidikan dan } \\
\text { pelatihan teknis fungsional } \\
\text { - Melaksanakan fasilitasi pendidikan dan } \\
\text { pelatihan teknis structural } \\
\text { - Melaksanakan urusan administrasi } \\
\text { pendidikan formal bagi ASN }\end{array}$ & $\begin{array}{c}\text { Badan Diklat Prov. Malut } \\
\text { di Ternate }\end{array}$ \\
\hline 5 & Diklat Aktual & $\begin{array}{l}\text { - Melaksanakan urusan pelaporan badan } \\
\text { - Melaksanakan urusan keuangan badan }\end{array}$ & $\begin{array}{l}\text { Kemendagri Pusdiklat } \\
\text { Regional Makassar } \\
\text { di Tidore }\end{array}$ \\
\hline 6 & $\begin{array}{l}\text { Diklat Penyusunan } \\
\text { RKA, Penyusunan } \\
\text { SPJ Bendahara } \\
\text { Pengeluaran \&Pajak }\end{array}$ & $\begin{array}{l}\text { - Melaksanakan urusan perencanaan badan } \\
\text { - Melaksanakan urusan keuangan badan } \\
\text { - Melaksanakan urusan pelaporan badan }\end{array}$ & $\begin{array}{l}\text { Lembaga Pengembangan } \\
\text { Manajemen Nasional } \\
\text { Jakarta }\end{array}$ \\
\hline 17 & $\begin{array}{l}\text { Diklat Penyusunan } \\
\text { Renstra dan Penge- } \\
\text { Iolaan Barang Milik } \\
\text { Daerah Mengguna- } \\
\text { kan Aplikasi }\end{array}$ & $\begin{array}{l}\text { - Melaksanakan urusan perencanaan badan } \\
\text { - Melakukan urusan perlengkapan badan } \\
\text { - Melakukan urusan kerumah tanggaan badan }\end{array}$ & $\begin{array}{c}\text { Lembaga Pengembangan } \\
\text { Manajemen Nasional } \\
\text { di Jakarta }\end{array}$ \\
\hline
\end{tabular}

Sumber: Olahan Data Sekunder, 2017.

Tabel 2 di atas secara singkat terlihat bahwa penentuan kebutuhan diklat di BKPSDM Kota Tidore Kepulauan sudah relevan dengan pekerjaan/tugas yang ada, namun jika ditelusuri lebih lanjut, maka akan ditemukan bahwa dalam menetukan kebutuhan diklat yang merujuk pada analisis pekerjaan/tugas dilaksanakan belum secara akurat menggambarkan analisis kebutuhan diklat yang obyektif dalam menetukan jenis diklat yang akan dilaksanakan masih bergantung pada apa yang ditawarkan oleh pihak Penyelenggara Diklat dalam menu yang ada dalam brosur atau undangan diklat.

Hal tersebut dapat diketahui dari hasil wawancara (19 Juni 2017) dengan Kepala BKPSDM, yang menjelaskan bahwa:

"Deskripsi pekerjaan dan spesifikasi pekerjaan itu harus jadi acuan kebutuhan diklat. Selama ini kami $\mathrm{men}$ y e s u a i k a n dengan surat-surat atau undangan diklat yang masuk dari $b$ e $r$ b a $g$ a $i$ penyelenggara diklat, kalau ada penyelenggaraan kegiatan diklat yang cocok buat kami biasanya Pak Husen (Sekretaris Badan) $\mathrm{l}$ a $\mathrm{n}$ g $\mathrm{s}$ u $\mathrm{n}$ g berkoordinasi dengan saya dan kalau memungkinkan ya kami akan kirim pegawai ke sana. Kepala-kepala Bidang juga berkoordiansi dengan saya tapi Sekretaris yang lebih sering karena setiap surat dan undangan yang masuk melalui sekretariat dan $\begin{array}{llllll}u & r & u & s & a & n\end{array}$ pengembangan PNS di internal kami BKPSDM serta anggarannya melekat di Sekretariat Badan, tapi pelaksanaannya tetap kita akomodir semua pegawai yang ada”. 
Penjelasan Kepala BKPSDM Kota Tidore Kepulauan menunjukan bahwa kegiatan diklat yang dilaksanakan masih merujuk pada jenis diklat yang ditawarkan oleh pihak-pihak penyelenggara diklat kemudian disesuaikan dengan pekerjaan/tugas yang ada, adapun urusan dan penganggaran terhadap pengembangan Pegawai Negeri Sipil di internal BKPSDM Kota Tidore Kepulauan melekat pada Bagian Sekretariat Badan.

Selanjutnya berdasarkan hasil wawancara (19 Juni 2017) dengan Kepala Sub Bagian Perencanaan dan Keuangan BKPSDM Kota Tidore Kepulauan, mengatakan bahwa:

“Tentunya setiap diklat yang kami ikuti selama ini sesuai dengan pekerjaan yang ada. Kami lihat di surat masuk dari penyelenggara diklat misalnya dari LPMN (Lembaga Pengembangan Manajemen Nasional), Badan Diklat atau yang lainnya kalau program diklat yang mereka tawarkan ada yang cocok trus anggaran memungkinkan saya akan kasi masukan ke Pak Sek (red: Sekretaris Badan) kemudian disampaikan ke Kaban ( r e d : Ke p a l a Badan) kalau disetujui ya kami langsung mendaftar untuk ikut”.

Berdasarkan
penjelasan dari
kedua informan
tersebut, dapat
dikatakan bahwa
dalam melakukan
analisis kebutuhan
diklat di internal
BKPSDM Kota Tidore Kepulauan, khususnya dalam menentukan jenis atau program diklat yang dibutuhkan dalam pekerjaan/tugas hanya bergantung pada menu diklat yang ditawarkan oleh pihak penyelenggara.

\section{Pelaksanaan Kebutuhan Diklat BKPSDM Kota Tidore Kepulauan Melalui Analisis Individu}

Berdasarkan informasi dari Kepala BKPSDM Kota Tidore Kepulauan menunjukkan bahwa dalam menentukan peserta diklat struktural atau diklat kepemimpinan yang merupakan salah satu syarat bagi PNS dalam menduduki jabatan struktural dengan merujuk pada peraturan maupun petunjuk teknis yang ada namun dalam menentukan pegawai yang telah memenuhi syarat untuk ikut dalam diklat kepemimpinan tingkat II, III, atau IV, keputusan akhirnya tergantung pada pilihan Walikota Tidore Kepulauan.

Berdasarkan dokumen yang ada pada Sistem Informasi Pelayanan Kepegawaian Kota Tidore Kepulauan ditemukan adanya kegiatan diklat yang sebenarnya penentuan pesertanya tidak sesuai dengan kebutuhan rill yang ada di BKPSDM Kota Tidore Kepulauan. Kondisi tersebut disajikan dalam tabel 3 dan 4, sebagai berikut:

\section{Tabel 3}

Data PNS BKPSDM Kota Tidore Kepulauan yang mengikuti Diklat Penyusunan RKA, Penyusunan SPJ Bendahara Pengeluaran dan Pajak

\begin{tabular}{|l|l|l|c|l|}
\hline No & Nama PNS \& Jabatan & Pendidikan Terakhir & \multicolumn{1}{|c|}{ Diklat } & $\begin{array}{l}\text { Pelanggaran } \\
\text { Disiplin }\end{array}$ \\
\hline 1 & $\begin{array}{l}\text { Kasubbag Umum dan } \\
\text { Kepegawaian }\end{array}$ & $\begin{array}{l}\text { Sarjana } \\
\text { Sosiologi }\end{array}$ & $\begin{array}{l}- \text { Prajabatan Gol. III } \\
- \text { Diklat Pim Tk. III }\end{array}$ & Tidak ada \\
\hline 2 & $\begin{array}{l}\text { Kasubbag Perencanaan } \\
\text { dan Keuangan }\end{array}$ & Sarjana IImu Hukum & Prajabatan Gol. III & Tidak ada \\
\hline 3 & $\begin{array}{l}\text { Staf Sub Bagian Umum } \\
\text { dan Perlengkapan / } \\
\text { Bendahara Barang }\end{array}$ & $\begin{array}{l}\text { Sarjana } \\
\text { Administrasi Negara }\end{array}$ & Prajabatan Gol. I & Tidak ada \\
\hline 4 & $\begin{array}{l}\text { Staf Sub Bagian Perencanaan } \\
\text { dan Keuangan / Pengadminis- } \\
\text { trasi Keuangan }\end{array}$ & $\begin{array}{l}\text { Sarjana } \\
\text { Sistem Informasi }\end{array}$ & Prajabatan Gol. II & Tidak ada \\
\hline
\end{tabular}

Sumber : Olahan Data Sekunder, 2017.

Pada tabel 3 tersebut dapat dilihat bahwa ada beberapa Pegawai yang menjadi Peserta dalam diklat tersebut tidak relevan dengan tugas dan 
fungsinya sebagai Pengadministri Persuratan (Arsiparis) dan pegawai yang memiliki tugas dan fungsi sebagai Bendahara Barang.

\section{Tabel. 4}

panggil suruh saya bawa SPPD deng Surat Tugas kasih tanda tangan di Kaban, saya liat saya pe nama ada, Alhamdulillah. Suda siap brangkat da, bagitu saja”.

Data PNS BKPSDM Kota Tidore Kepulauan yang mengikuti Diklat Penyusunan Renstra dan Pengelolaan Barang Milik Daerah

\begin{tabular}{|c|l|l|l|l|}
\hline No & Nama PNS \& Jabatan & Pendidikan Terakhir & Diklat & $\begin{array}{l}\text { Pelanggaran } \\
\text { Disiplin }\end{array}$ \\
\hline 1 & $\begin{array}{l}\text { Staf Sub Bagian Perencanaan } \\
\text { dan Keuangan / Bendahara Gaji }\end{array}$ & $\begin{array}{l}\text { Sarjana } \\
\text { Administrasi Negara }\end{array}$ & Prajabatan Gol. II & Tidak ada \\
\hline 2 & $\begin{array}{l}\text { Staf Sub Bagian Perencanaan } \\
\text { dan Keuangan / Pengadminis- } \\
\text { trasi Keuangan }\end{array}$ & $\begin{array}{l}\text { Sarjana } \\
\text { Sistem Informasi }\end{array}$ & Prajabatan Gol. II & Tidak ada \\
\hline 3 & $\begin{array}{l}\text { Staf Sub Bagian Umum dan } \\
\text { Kepegawaian / Pengemudi }\end{array}$ & $\begin{array}{l}\text { SLTA } \\
\text { IPS }\end{array}$ & Prajabatan Gol. II & Tidak ada \\
\hline 4 & $\begin{array}{l}\text { Staf Sub Bagian Perencanaan } \\
\text { dan Keuangan / Pengadminis- } \\
\text { trasi Umum }\end{array}$ & $\begin{array}{l}\text { SMK } \\
\text { Koperasi }\end{array}$ & Prajabatan Gol. II & Tidak ada \\
\hline
\end{tabular}

Berdasarkan keterangan dari kedua informan tersebut, dapat katakan bahwa dalam menentukan kebutuhan diklat di BKPSDM Kota Tidore Kepulauan tidak dilaksanakan melalui analisis individu dalam menetukan pegawai yang diikutkan

Tabel 4 menunjukkan bahwa diklat tersebut tidak relevan dengan pegawai yang memiliki tugas dan fungsi sebagai Pengemudi dan pegawai yang memiliki tugas dan fungsi sebagai Bandahara Gaji.

Kemudian berdasarkan hasil wawancara dengan Staf (Bendahara Barang) BKPSDM Kota Tidore Kepulauan, terungkap sebagai berikut: "Ya saya ikut diklat itu. Pak Sek (red: Sekretaris Badan) cuma panggil saya kasi tau kalau saya dikasi ikut diklat ini dengan teman-teman yang lain di Jakarta. Ya saya bilang siap saja. Torang staf ini klo diperintahkan harus siap to".

Penjelasan Bendahara Barang tersebut memperlihatkan bahwa BKPSDM Kota Tidore Kepulauan dalam menentukan Pegawai yang mengikuti diklat hanya berdasarkan penunjukan dari Pimpinan.

Senada dengan itu berdasarkan hasil wawancara (19 Juni 2017) dengan Staf Pengemudi BKPSDM Kota Tidore Kepulauan, menyatakan bahwa:

"Benar saya ikut. Waktu itu di otto Kaban (Kepala Badan) ada tanya saya mau ikut diklat di Jakarta atau tidak?. Saya bilang mau, trus besok Pak Sek dalam kegiatan diklat hanya melalui penunjukan berdasarkan intuisi atau keinginan dari Pimpinan.

\section{PEMBAHASAN}

Manusia merupakan aset terpenting dalam suatu organisasi, karena berkembang tidaknya suatu organisasi sangat bergantung pada kualitas sumber daya menusia yang dimiliki. Untuk itu, pengetahuan tentang manajemen sumber daya manusia adalah penting untuk diketahui oleh setiap organasitoris dalam hal ini pengetahuan mengenai manajemen sumber daya manusia akan memberikan pemahaman tentang bagaimana mengelola potensi manusia yang ada dalam organisasi.

Mathis dan Jackson (2006) mengemukakan bahwa sumber daya manusia adalah rancangan sistem-sistem formal dalam sebuah organisasi untuk memastikan penggunaan bakat manusia secara efektif dan efisien. Secara sederhana manajemen sumber daya manusia dapat diartikan sebagai upaya dalam mengelola segala potensi yang ada pada setiap individu dalam organisasi guna mencapai tujuan-tujuan organisasi. 
Kemudian pengembangan sumber daya manusia dapat diartikan sebagai suatu kegiatan yang harus dilakukan oleh organisasi agar pengetahuan, kemampuan, dan keterampilan mereka sesuai dengan tuntutan pekerjaan yang mereka lakukan. Pengembangan merupakan proses di mana karyawan memperoleh keterampilan dan pengalaman agar berhasil pada pekerjaan sekarang dan tugas-tugas di masa yang akan datang (Kaswan, 2011). Pengembangan sumber daya manusia merupakan langkah antisipatif terhadap perubahan dimasa depan dan sebuah usaha untuk mencapai keberhasilan pada pekerjaan saat ini.

Pendekatan sistematis untuk menemukan kebutuhan-kebutuhan seyogyanya dilakukan dalam upaya pengembangan sumber daya manusia, guna mencapai hasil maksimal yang sesuai dengan kebutuhan dan tujuan organisasi. Menurut pendapat para ahli, langkah ini dapat dilakukan melalui tiga tingkatan analisis yaitu: analisis organisasi, analisis pekerjaan, dan analisis individu. Analisis kebutuhan diklat adalah suatu proses yang sistematis dalam mengidentifikasi ketimpangan antara sasaran dengan keadaan nyata atau diskrepansi antara kinerja standar dan kinerja nyata yang penyelesaiannya melalui diklat (Lembaga Administrasi Negara, 2005).

Metode dan pendekatan yang obyektif dan sistematis diperlukan dalam melaksanakan analisis kebutuhan diklat agar dapat mengetahui kesenjangan yang ada sehingga dapat menentukan kebutuhan diklat dengan tepat dan akurat. Simamora (2004) mengemukakan bahwa dalam penilaian kebutuhan pelatihan terdapat beberapa metode dalam upaya pengumpulan data sebagai informasi analisis diantaranya adalah meninjau data bisnis, wawancara, fokus kelompok, kuesioner, kejadian kritis, observasi, menelaah data kinerja, diskusi informal, dan menelaah deskripsi pekerjaan.
Adapun manfaat analisis kebutuhan pelatihan menurut Lembaga Administrasi Negara (2009) antara lain:

1. Program-program diklat yang disusun sesuai dengan kebutuhan organisasi, jabatan maupun individu setiap pegawai.

2. Menjaga dan meningkatkan motivasi peserta dalam mengikuti pelatihan, karena program pelatihan yang diikuti sesuai dengan kebutuhannya. Dengan demikian akan mencapai efektifitas pencapaian tujuan pelatihan.

3. Efisiensi biaya organisasi karena pelatihan yang dilaksanakan sesuai dengan kebutuhan organisasi. Jadi biaya yang tidak sedikit yang dikeluarkan untuk pelatihan tidaklah sia-sia.

4. Memahami penyebab timbulnya masalah dalam organisasi, karena pelaksanaan penilaian kebutuhan yang tepat dan efektif, akan mengungkap masalah-masalah yang ditimbulkan oleh diskrepansi kompetensi pegawai/ pekerja.

Kemudian menurut Hartania (2016), program pelatihan sebenarnya ditujukan agar tercapainya kinerja perusahaan yang maksimum, meningkatnya pengetahuan, sikap, keterampilan, dan pengembangan karir. Program diklat merupakan salah satu kegiatan yang penting dan dapat dijadikan investasi organisasi dalam hal sumber daya manusia.

Berdasarkan pendapat di atas, dapat dikatakan bahwa analisis kebutuhan diklat bertujuan untuk mendapatkan informasi yang akurat dalam rangka menentukan langkah diklat yang tepat dan sesuai dengan kebutuhan organisasi. Selain itu, kesesuaian program-program diklat dengan kebutuhan organisasi secara menyeluruh menjaga dan meningkatkan motivasi Peserta yang mengarah pada efektivitas tujuan 
pelatihan, efisiensi biaya pelatihan, dan lebih memahami penyebab timbulnya masalah-masalah dalam organisasi. Hal inilah merupakan manfaat analisis kebutuhan diklat yang dilaksanakan melalui suatu proses tahapan yang sistematis.

\section{Analisis Organisasi}

Dalam analisis kebutuhan diklat dilakukan analisis organisasi yang mencakup lingkungan organisasi beroperasi, tujuan organisasi, sumber daya manusianya, dan iklim organisasi. Menurut Mondy (2008) kegiatan analisis organisasi dimulai dari perspektif organisasi secara menyeluruh, misi-misi, tujuan-tujuan, dan rencana-rencana strategik organisasi dipelajari, bersama dengan hasil perencanaan sumber daya manusia. Analisis organisasi membutuhkan penilaian terhadap lingkungan organisasi baik internal maupun eksternal.

Selanjutnya, Cascio (2003) mengemukakan bahwa analisis organisasi berfokus pada identifikasi dimana dalam organisasi diperlukan pelatihan. Berdasarkan teori-teori tersebut dapat diketahui bahwa analisis kebutuhan diklat melalui analisis organisasi berdasarkan pada tujuan dan strategi organisasi akan dapat menjawab bagian mana dalam organisasi yang memerlukan program pendidikan dan/ atau pelatihan.

Dalam melakukan analisis kebutuhan diklat melalui suatu proses analisis organisasi yang bertujuan untuk menentukan pada bagian atau bidang mana dalam organisasi yang membutuhkan kegiatan diklat seyogyanya dilaksanakan melalui penilaian yang teliti terhadap pencapaian visi, misi tujuan dan rencana strategik organisasi serta pertimbangan terhadap hasil perencanaan sumber daya manusia yang dapat diketahui melalui analisis dari hasil wawancara keluar, survai peserta dan data kepuasan Peserta maupun dengan melihat indeks efisiensi. Namun berdasarkan hasil wawancara, telaah dokumen dan observasi yang telah dilaksanakan menujukan bahwa analisis kebutuhan diklat yang dilaksanakan di BKPSDM Kota Tidore Kepulauan belum melaksanakan langkah-langkah tersebut, dimana selama ini hanya berdasarkan pada intuisi atau keinginan dari pimpinan.

\section{Analisis Pekerjaan/Tugas}

Perangkat dasar manajemen sumber daya manusia adalah analisis pekerjaan, dimana analisis ini memberikan ringkasan mengenai kewajiban dan tanggung jawab suatu pekerjaan, hubungannya dengan pekerjaan lainnya, pengetahuan dan keterampilan yang dibutuhkan, dan lingkungan kerja di mana pekerjaan tersebut dijalankan. Mondy (2008) mengemukakan bahwa analisis pekerjaan merupakan teknik sumber daya manusia yang mendasar dan menyeluruh serta merupakan titik awal bagi bagi aktivitas-aktivitas sumber daya manusia lainnya.

Noe, et.al. (2010) berpendapat bahwa analisis tugas meliputi mengidentifikasi tugas-tugas dan pengetahuan, keterampilan, serta berbagai perilaku penting yang perlu ditekankan pada pelatihan bagi para karyawan agar dapat menyelesaikan tugas-tugasnya. Melalui analisis tugas/ pekerjaan kita dapat mengidentifikasi pengetahuan, keterampilan dan sikap apa yang dibutuhkan dalam suatu pekerjaan tertentu sehingga dapat menentukan jenis atau program diklat dengan tepat.

Analisis pekerjaan memerlukan pemeriksaan hati-hati terhadap pekerjaan yang akan dilakukan setelah pelatihan. Ini melibatkan kumpulan sistematis informasi yang menggambarkan bagaimana pekerjaan dilakukan, sehingga standar kinerja untuk pekerjaannya dapat ditentukan, dan bagaimana tugas-tugas yang harus 
dilakukan untuk memenuhi standar, serta kompetensi yang diperlukan untuk kinerja tugas yang efektif, analisis pekerjaan, penilaian kinerja, wawancara (dengan pemegang pekerjaan, pengawas, dan manajemen yang lebih tinggi), dan analisis masalah operasi (kontrol kualitas, laporan tentang tidak beroperasinya mesin, dan keluhan pelanggan) semua memberikan masukan penting untuk analisis kebutuhan pelatihan (Cascio, 2003).

Analisis pekerjaan/tugas melibatkan kumpulan sistematis informasi yang menggambarkan bagaimana pekerjaan dilakukan, sehingga standar kinerja untuk pekerjaannya dapat ditentukan, bagaimana tugas-tugas yang harus dilakukan untuk memenuhi standar, dan kompetensi yang diperlukan untuk kinerja tugas yang efektif. Analisis pekerjaan/tugas berfokus pada tugastugas yang diperlukan untuk mencapai tujuan-tujuan organisasi. Deskripsi dan spesifikasi pekerjaan merupakan sumber yang penting untuk mengetahui jenis diklat apa yang dibutuhkan. Kesenjangan yang terjadi pada pekerjaan atau tugas dapat diketahui melalui suatu penarikan sampel kerja, wawancara ke dalam tentang pekerjaan atau tugas maupun dengan menelaah persyaratan pekerjaan yang ada pada BKPSDM Kota Tidore Kepulauan, namun selama ini dalam menentukan jenis atau program diklat yang dibutuhkan BKPSDM Kota Tidore Kepulauan belum melakukan langkahlangkah analisis pekerjaan atau tugas secara sistematis, di mana BKPSDM Kota Tidore Kepulauan masih sangat bergantung pada program diklat yang ditawarkan oleh pihak penyelenggara diklat.

\section{Analisis Individu}

Setelah mengetahui pada bagian mana dalam organisasi yang perlu untuk memerlukan program pengembangan melalui kegiatan diklat dan mendapatkan informasi tentang apa yang harus dipelajari Peserta Diklat, maka tahapan selanjutnya adalah melakukan analisis individu. Menentukan kebutuhan pelatihan individual merupakan level terakhir. Untuk menentukan siapa yang perlu dilatih serta pengetahuan, keterampilan dan kemampuan jenis apa yang dibutuhkan para karyawan. Penilaian kinerja serta wawancara atau survai terhadap supervisor dan pemegang pekerjaan sangat membantu pada level ini (Mondy, 2008).

Fokus penilaian dalam analisis individu adalah kesenjangan atau gap antara kinerja saat ini dengan standar kinerja yang diharapkan terdapat pada Pegawai Pemegang Jabatan/tugas tertentu. Noe et.al (2010) menjelaskan bahwa titik tekanan utama dari pelatihan adalah kinerja yang rendah atau di bawah standar, yakni kesenjangan antara kinerja pegawai saat ini dengan kinerja yang diharapkan. Kinerja yang rendah ditujukan dengan adanya keluhan dari pengguna layanan, penilaian kinerja yang rendah, kecelakaan di tempat kerja, atau perilaku yang membahayakan. Indikator potensial lainnya dari kebutuhan pelatihan adalah jika perubahan pekerjaan mengakibatkan tingkat kinerja saat ini perlu ditingkatkan atau para karyawan harus menyelesaikan tugas-tugas yang baru.

Sejalan dengan pendapat tersebut di atas, penjelasan tentang analisis individu menurut Cascio (2003) adalah bahwa pada tingkat ini kebutuhan pelatihan dapat didefinisikan dalam hal ide umum berikut: perbedaan antara kinerja yang diinginkan dan kinerja aktual ini adalah kebutuhan pelatihan individu tersebut. Standar kinerja, yang diidentifikasi dalam tahap analisis pekerjaan, merupakan pembuktian kinerja yang diinginkan. Kinerja aktual masingmasing Pegawai dapat dibandingkan dengan standar yang mewakili kinerja yang diinginkan dengan menggunakan informasi seperti berikut: (1) data kinerja individu; (2) peringkat diagnostik Karyawan dengan Atasan Langsung, Rekan-Rekan, atau Pelanggan; (3) catatan 
kinerja yang disimpan oleh Pekerja dalam bentuk buku harian; (4) survai sikap; wawancara; atau tes (pengetahuan pekerjaan, contoh kerja, atau situasional). Kesenjangan antara kinerja aktual dan yang diinginkan dapat diisi oleh pelatihan.

Penilaian kinerja menjadi fokus perhatian pada tahapan analisis ini. Menurut Simamora (2004) analisis personalia (personnel analysis) mengidentifikasikan kesenjangan antara kebutuhan kerja dan kebutuhan organisasi yang teridentifikasi dengan karakteristik masing-masing pegawai. Perbedaan antara kinerja yang diharapkan dengan kinerja sesungguhnya merupakan kebutuhan pelatihan individu. Standar kinerja yang ditentukan dalam tahap analisis operasional menjadi kinerja yang didambakan. Data kinerja individu, nilai diagnostik karyawan oleh penyelia, catatan kinerja yang disimpan karyawan dalam formulir harian, survai sikap, wawancara, atau tes dapat menyodorkan informasi tentang kinerja aktual untuk dibandingkan dengan tolok ukur kinerja yang dikehendaki dari setiap karyawan. Kesenjangan antara kinerja aktual dan yang diinginkan dapat dijembatani oleh pelatihan.

Berdasarkan uraian-uraian tersebut dapat diketahui bahwa tahapan terakhir analisis kebutuhan diklat yaitu melalui analisis individu yang dapat memberikan informasi tentang siapa yang perlu dilatih atau dididik dan latihan atau pendidikan apa yang perlu diberikan agar dapat menutupi kesenjangan kinerja yang terdapat pada pegawai tersebut.

Dalam melakukan analisis kebutuhan diklat untuk individu seyogyanya dilaksanakan dengan menganalisa data kinerja individu, nilai diagnostik Pegawai oleh Atasan mereka, survai sikap, wawancara, atau tes kompetensi dapat menyodorkan informasi tentang kinerja aktual untuk dibandingkan dengan tolak ukur kinerja yang dikehendaki dari setiap pegawai yang ada. Namun selama ini di BKPSDM Kota Tidore Kepulauan dalam menentukan siapa saja Pegawai yang harus dan layak diikutkan dalam suatu kegiatan diklat hanya berdasarkan keinginan atau inituisi dari pimpinan. Dasar penunjukan peserta diklat seperti ini yang menyebabkan kegiatan diklat tidak berhasil menutupi kesenjangan kompetensi pegawai yang ada akhirnya berimplikasi pelaksanaan pekerjaan dan tugas yang tidak efektif dan kurang efisien (tidak sesuai harapan) dan tidak memberi dampak positif pada kinerja organisasi dalam mencapai tujuannya.

\section{KESIMPULAN DAN SARAN}

Kami menyimpulkan bahwa BKPSDM Kota Tidore Kepulauan belum melaksanakan analisis kebutuhan diklatnya melalui tahapan analisis kebutuhan diklat yang tepat dan sistematis. Identifikasi kebutuhan diklat di tingkat organisasi hanya ditentukan oleh Pimpinan, identifikasi kebutuhan diklat di tingkat pekerjaan hanya menyesuaikan dengan program program diklat yang ditawarkan oleh penyelenggara diklat, dan kebutuhan diklat di tingkat individu hanya diputuskan oleh Pimpinan berdasarkan intuisi dan keinginannya. Oleh karena itu sebaiknya, BKPSDM Kota Tidore Kepulauan dalam menentukan bagian atau bidang mana dalam organisasi yang membutuhkan diklat melaksanakan analisis organisasi dengan melakukan wawancara keluar, survai Peserta atau data kepuasan Peserta maupun dengan melihat indeks efisiensi. Untuk menentukan jenis atau program diklat yang dibutuhkan dalam pekerjaan/tugas yang ada dilaksanakan melalui suatu proses analisis pekerjaan/tugas melalui penarikan sampel kerja, wawancara ke dalam tentang pekerjaan atau tugas maupun dengan menelaah persyaratan pekerjaan yang ada. Selanjutnya, untuk 
menentukan Pegawai yang harus dan layak mengikuti suatu program diklat dilaksanakan melalui suatu proses analisis individu dengan cara memeriksa data kinerja individu, skala penilaian kinerja Pegawai, survai sikap, wawancara, atau tes kompetensi (pengetahuan keterampilan dan sikap) yang dapat memberikan informasi tentang kinerja aktual untuk dibandingkan dengan tolok ukur kinerja yang dikehendaki dari setiap Pegawai yang ada secara akurat. Selain itu, BKPSDM Kota Tidore Kepulauan perlu mengirim pegawainya mengikuti diklat analisis kebutuhan diklat pada penyelenggara diklat terakreditasi.

\section{REFERENSI}

Cascio, Wayne F. 2003. Managing Human Resources: Productvity, Quality of Work Life, Profits. New York: McGraw-Hill Companies, Inc.

Hartania, Putu N. 2016. Analisis Kebutuhan Pelatihan Karyawan Pada Hotel Puri Saron. Jurnal Manajemen. 1 (4). p 1-11 [on line].

Kaswan. 2011. Pelatihan dan Pengembangan: Untuk Meningkatkan Kinerja SDM. Bandung: Alfabeta.
Lembaga Administrasi Negara. 2005. Konsep Dasar AKD: Bahan Diklat Bagi Analis Kebutuhan Diklat. Jakarta.

Analisis Kebutuhan Diklat: Bahan Diklat Bagi Pengelola Diklat. Jakarta.

Mathis, Robert L and Jackson, John H. 2006. Human Resource Management: Manajemen Sumber Daya Manusia. Jakarta: Salemba Empat.

Miles, Matthew B and Huberman, A Michael. 1992. Analisis Data Kualitatif: Buku Sumber Tentang Metode-Metode Baru. Jakarta: Salemba Empat.

Mondy, R Wayne. 2008. Manajemen Sumber Daya Manusia. Jilid ke-1. Edisi ke-10, Jakarta: Erlangga.

Noe, Raymond A, et.all. 2010. Manajemen Sumber Daya Manusia: Mencapai Keunggulan Bersaing. Edisi ke-6. Cet.ke-1. Jakarta: Salemba Empat.

Simamora, H. 2004. Manajemen Sumber Daya Manusia. Edisi ke-3. Yogyakarta: Bagian Penerbitan Sekolah Tinggi Ilmu Ekonomi YPKN. 